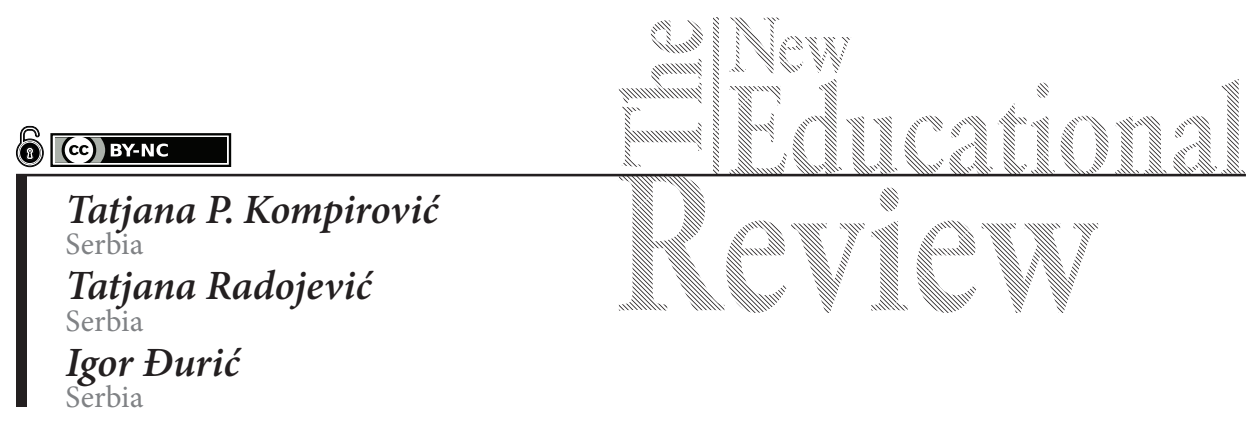

\title{
The Correlation Between Parenting Styles and Childrens' Social Competences and Anti-social Behavior ${ }^{1}$
}

DOI: 10.15804/tner.2020.62.4.03

\begin{abstract}
Family relationships and parents' behavior towards their children are factors that significantly influence the development of a child's personality and their behavior modeling. Parenting styles are often seen as having an impact on their child's social functioning. Having this in mind, this paper presents the results of research on key aspects of the influence that parenting styles have on the development of social competences and anti-social behavior in children. Standardized instruments (SSBS-2 and VS scale) were used in the research, and the sample included a total number of 705 students and 44 head-class teachers ${ }^{2}$. The research was conducted in primary schools on the territory of Kosovo and Metohija (Serbia). The results obtained indicated a correlation between parenting styles and students' social competences and anti-social behavior, with a mother's detached attitude standing out as a negative predictor of children's social functioning.
\end{abstract}

Key words: family, parenting styles, social competences, anti-social behaviors

1 The paper is the result of the research conducted within the research project III 47023 , Косово и Метохија између националног идентитета и евроинтеграција (Кosovo and Metohija between national identity and eurointegration) funded by the Ministry of Education, Science and Technological Development of the Republic of Serbia.

2 In Serbian primary/secondary education, there is a teacher-in-charge-of-the-class, dealing with the general administrative tasks related to it - student's discipline, absences, medical certificates, statistics, and various organizational matters - raising money, trips, visits, etc. 


\section{Introduction}

Family, as the basic social environment in which a personality is developed and formed, represents an important factor in the development of any individual or society on the whole. It is the most important context in the provision of child rearing models under which the social development of children and young people are carried out. Family and acquired behavior patterns within it are directly connected to a child's behavior because the child largely adopts the behavior it sees in their family. It is for these reasons that we developed our interest in studying the connection between parenting styles and social competences and anti-social behaviors in children.

In literature dealing with this issue, there are many claims supporting the fact that the family environment, parent-child interaction at home and parental actions influence the child's behavior in and beyond another important environment - school. Hence, we were determined to examine the issue of the relationship between parenting styles and social competencies and anti-social behaviors in children within these two systems. For these reasons, we set the research itself in a school framework, trying to obtain the empirical indicators for this relationship.

\section{Parenting styles, social competences and anti-social behaviors of children}

Parenting styles. Parental behavior and actions have a direct impact on the child, their needs, and the development of their specific attitudes and characteristics. Parental conduct is complex and provides no uniform answers to the question of how to behave toward children of different age groups and in different situations. It is in the selection of child-rearing techniques and the behavior of parents towards children that their parenting style is. Parenting style is defined ,as a constellation of parents' attitudes and behaviors toward children and an emotional climate in which the parents' behaviors are expressed“ (Darling \& Steinberg, 1993: 493). The emotional factor (love, hate, coldness, tenderness) is considered to be the most important component of parenting style.

More significant interest in research into parenting styles emerged in the 1930s in the USA through the works of E.S. Schaefer, and later Diane Baumrind (Schaefer, 1959; Baumrind, 1966). Relying on Schaefer's model, Baumrind defined three basic types of parent-child relationships: authoritarian, authoritative, and 
permissive. Maccoby and Martin (1983, according to Darling \& Steinberg, 1993) singled out another cold-indulgent (indifferent) type of parenting.

The Authoritarian parenting style is also referred to as cold-limiting, due to the pronounced dimension of control and the parents' cold/detached upbringing. For Baumrind (1966), authoritarian parenting style refers to the actions of parents who have high expectations and demands for their children. An authoritarian style of parenting is reflected in the parents' demanding and restrictive behavior who highly value discipline and conformation, and do not show much love and warmth. Authoritarian parents are cold and strict, they constrain initiative, spontaneity and freedom of opinion; they are uncompromising, set high demands and expect the child to blindly adhere to set rules, very often with the use of force. The consequence of authoritarian parenting styles is a low degree of pro-social, and a high degree of aggressive and anti-social behavior (Deković \& Janssens, 1992).

The authoritative, or warm-restrictive parenting style, is typical of parents who encourage verbal communication and child's initiative. This style is characterized by a relatively high, but still reasonable, level of control, which is adjusted according to the child`s age. Authoritative parenting style represents the midpoint between authoritarian and permissive parenting style and involves restrictive and responsible parental behavior, but with a higher degree of understanding. Children who come from authoritative (warm-restrictive) families are curious, confident, independent and academically successful. The research, conducted by Grolnick \& Ryan (1989), revealed that children of authoritative parents showed greater social competence. These children had better self-control and fewer adjustment problems at school than children of parents who were rated as very controlling (authoritarian).

The permissive or warm-lenient style of parenting is typical of parents who behave with impunity, acceptance and affirmation to the impulses, desires and actions of their children. The permissive parenting style is described as non-restrictive, warm and accepting, but does not involve setting clear boundaries in parenting. This style is characterized by low levels of control followed by acquiescence to the demands of the child. Research shows that adolescents of permissive parents do not adhere to rules and boundaries, which they do not take seriously, and consequently find it difficult to establish self-control and have a tendency towards egocentric behavior (Kopko, 2007).

The indifferent parenting style or cold-lenient type of parenting is typical of parents who are emotionally and physically detached from their children, and who show a low level of care and support for their children. The indifferent parenting style is reflected in setting few restrictions, but also in providing scant attention, 
engagement, and emotional support. This style is most often associated with the least desirable developmental outcomes in children because it does not encourage their adequate social development (Steinberg, 2001). Children of indifferent parents do not participate adequately in social interactions, are prone to aggressive behavior towards others, and are socially distanced. Since they spend a lot of time without supervision and parental control, adolescents who show various forms of socially unacceptable behavior tend to be the product of this kind of parenting style.

Social competence and anti-social behaviors of children. There are numerous definitions of social competence; however, what they all have in common is that the possession of social competences implies the efficient and effective functioning of an individual in social situations. Social competences represent a set of built-up abilities and skills in achieving one's personal goals and social interactions, simultaneously maintaining positive relationships with others over time and in different situations (Petrović, 2008). As socially competent behaviors in school environment, for the purposes of this paper, the quality of interpersonal relationships, self-management (i.e. control of one's own behavior) and academic skills were taken into account. The frequent manifestation of these skills indicates good social adjustment to the school environment in adolescence.

Anti-social behavior is defined as behavior that hinders adequate socialization, that is destructive and harmful, and that produces negative social outcomes (Walker, Colvin \& Ramsey, 1995). As anti-social behaviors in the school period, the manifestation of externalized forms of behavior (e.g. disobedience, impulsivity, hostility, irritability, insolence, aggression) was studied. These behaviors can be manifested in the form of interfering with the work of teachers and other students, open expression of aggression (physical and verbal), hostile attitudes and disrespect towards others, disrespect for other people's possessions, school inventory, etc.

\section{Method}

The aim of the study was to investigate the relationship between parenting styles and social competences and anti-social behavior of the students. The set goal was realized through an assessment of students' social competences and anti-social behaviors by the head-class teachers and the assessment of parenting styles (mother and father respectively) by the students.

The School of Social Behavior Scales (SSBS-2) was used in the research (The School Social Behavior Scales, Second Edition, Merrell, 2002). It consists of 64 
items, divided into two subscales and six empirically derived factors (Social Competence Subscale: Peer Relationships, Self-Behavior Management, Academic Behavior; Anti-social Behavior Subscale: Hostile/Irritable Behavior, Anti-social/ Aggressive Behavior).The Scale of Educational Attitudes (VS scale) was also used in the research. It is intended to examine children's perception of parental styles (Genc \& Kodžopeljić, 1995). Constructed according to Schaefer's two-dimensional model of child rearing that reduces this complex phenomenon to two dimensions: affective and control, this scale measures four poles of these dimensions: warm, cold, limiting and lenient attitude.

The research was carried out in fifteen schools on the territory of Kosovo and Metohija (Serbia), and included students from the final grades of primary school (seventh and eighth grade students) as well as their head-class teachers. The total sample consisted of 705 students and 44 head-class teachers.

Data collection was performed using a scaling technique. The SPSS program was used for data processing, namely the following statistical measures and procedures: Pearson's linear correlation coefficient and regression analysis.

\section{Research results}

The relationship between parenting styles and the students' social competences was investigated using the Pearson linear correlation coefficient.

Table 1. Correlations between parents' attitudes and students' social competences

\begin{tabular}{|c|c|c|c|c|c|}
\hline \multicolumn{2}{|c|}{ Variables } & \multirow{2}{*}{$\begin{array}{c}\begin{array}{c}\text { Peer relation- } \\
\text { ships }\end{array} \\
.129^{* *}\end{array}$} & \multirow{2}{*}{$\begin{array}{c}\begin{array}{c}\text { Self-behavior } \\
\text { management }\end{array} \\
.114^{\star \star}\end{array}$} & \multirow{2}{*}{$\begin{array}{r}\begin{array}{c}\text { Academic } \\
\text { behavior }\end{array} \\
.126^{\star *}\end{array}$} & \multirow{2}{*}{$\begin{array}{c}\begin{array}{c}\text { Social com- } \\
\text { petences. - } \\
\text { Scale A }\end{array} \\
.131^{\star *} \\
\end{array}$} \\
\hline Father - & Pearson Corr. & & & & \\
\hline warm attitude & Sig. (2-tailed) & .001 & .003 & .001 & .001 \\
\hline \multirow{2}{*}{$\begin{array}{l}\text { Mother - } \\
\text { warm attitude }\end{array}$} & Pearson Corr. & $.152^{\star *}$ & $.124^{\star \star}$ & $.153^{\star *}$ & $.153^{\star *}$ \\
\hline & Sig. (2-tailed) & .000 & .001 & .000 & .000 \\
\hline \multirow{2}{*}{$\begin{array}{l}\text { Father - cold } \\
\text { attitude }\end{array}$} & Pearson Corr. & $-.219^{* \star}$ & $-.216^{\star \star}$ & $-.270^{\star *}$ & $-.243^{\star *}$ \\
\hline & Sig. (2-tailed) & .000 & .000 & .000 & .000 \\
\hline \multirow{2}{*}{$\begin{array}{l}\text { Mother - } \\
\text { cold attitude }\end{array}$} & Pearson Corr. & $-.237^{\star *}$ & $-.235^{\star \star}$ & $-.285^{\star *}$ & $-.262^{\star *}$ \\
\hline & Sig. (2-tailed) & .000 & .000 & .000 & .000 \\
\hline \multirow{2}{*}{$\begin{array}{l}\text { Father - leni- } \\
\text { ent attitude }\end{array}$} & Pearson Corr. & $.134^{\star *}$ & $.141^{\star \star}$ & $.130^{\star *}$ & $.142^{\star *}$ \\
\hline & Sig. (2-tailed) & .000 & .000 & .001 & .000 \\
\hline
\end{tabular}




\begin{tabular}{|c|c|c|c|c|c|}
\hline \multicolumn{2}{|c|}{ Variables } & \multirow{2}{*}{$\begin{array}{c}\begin{array}{c}\text { Peer relation- } \\
\text { ships }\end{array} \\
.120^{\star *}\end{array}$} & \multirow{2}{*}{$\begin{array}{c}\begin{array}{c}\text { Self-behavior } \\
\text { management }\end{array} \\
.124^{\star \star}\end{array}$} & \multirow{2}{*}{$\begin{array}{c}\begin{array}{c}\text { Academic } \\
\text { behavior }\end{array} \\
.134^{\star *}\end{array}$} & \multirow{2}{*}{$\begin{array}{c}\begin{array}{c}\text { Social com- } \\
\text { petences. - } \\
\text { Scale A }\end{array} \\
.131^{\star *}\end{array}$} \\
\hline Mother - le- & Pearson Corr. & & & & \\
\hline nient attitude & Sig. (2-tailed) & .001 & .001 & .000 & .000 \\
\hline \multirow{2}{*}{$\begin{array}{l}\text { Father - lim- } \\
\text { iting attitude }\end{array}$} & Pearson Corr. & $-.139^{* *}$ & $-.137^{\star \star}$ & $-.184^{\star *}$ & $-.157^{\star *}$ \\
\hline & Sig. (2-tailed) & .000 & .000 & .000 & .000 \\
\hline \multirow{2}{*}{$\begin{array}{l}\text { Mother - } \\
\text { limiting } \\
\text { attitude }\end{array}$} & Pearson Corr. & $-.130^{* *}$ & $-.136^{\star *}$ & $-.165^{\star *}$ & $-.148^{* *}$ \\
\hline & Sig. (2-tailed) & .001 & .000 & .000 & .000 \\
\hline
\end{tabular}

${ }^{\star} \mathrm{p}<.05,{ }^{* *} \mathrm{p}<.01$.

The results indicate a connection between parenting styles and all examined forms of students' social competences (Table 1). The results are very similar for mothers and fathers and show that a warm and lenient upbringing is associated with a higher level of social competence. On the other hand, a cold and restrictive parenting style is associated with a lower level of social competence of children in all factors (peer relationships, self-behavior management and academic behavior).

In order to examine the relationship between predictor and dependent variables more accurately, four standard multiple regression analyzes were performed (Tables 2 and 3).

Table 2. Standard regression analysis for dependent variables Peer relationships and Self-behavior management

\begin{tabular}{|c|c|c|c|c|c|c|}
\hline \multirow[b]{2}{*}{ Predictors } & \multicolumn{3}{|c|}{ Peer relationships } & \multicolumn{3}{|c|}{ Self-behavior management } \\
\hline & $R^{2}$ & $F$ & B & $R^{2}$ & $F$ & B \\
\hline Parental styles & .065 & $5.848^{\star * *}$ & & .063 & $5.654^{\star * *}$ & \\
\hline 1. Father - warm attitude & & & .067 & & & -.053 \\
\hline 2. Mother - warm attitude & & & .076 & & & .011 \\
\hline 3. Father - cold attitude & & & -.017 & & & -.044 \\
\hline 4. Mother - cold attitude & & & $-.180^{\star}$ & & & -.164 \\
\hline 5. Father - lenient attitude & & & .090 & & & .111 \\
\hline 6. Mother - lenient attitude & & & .009 & & & .003 \\
\hline 7. Father - limiting attitude & & & -.061 & & & -.041 \\
\hline 8.Mother - limiting attitude & & & .025 & & & .008 \\
\hline
\end{tabular}

${ }^{\star} \mathrm{p}<.05,{ }^{* *} \mathrm{p}<.01,{ }^{* * *} \mathrm{p}<.001$. 
Table 3. Standard regression analysis for dependent variables Academic behavior and Social competence (scale A)

\begin{tabular}{|c|c|c|c|c|c|c|}
\hline & \multicolumn{3}{|c|}{ Academic behavior } & \multicolumn{3}{|c|}{ Scale A } \\
\hline Predictors & $R^{2}$ & $F$ & B & $R^{2}$ & $F$ & B \\
\hline Parental styles & .091 & $8.419^{* * *}$ & & .077 & $7.031^{\star * *}$ & \\
\hline 1. Father - warm attitude & & & .047 & & & .061 \\
\hline 2. Mother - warm attitude & & & .026 & & & .049 \\
\hline 3. Father - cold attitude & & & -.063 & & & -.038 \\
\hline 4. Mother - cold attitude & & & $-.194^{*}$ & & & $-.188^{\star}$ \\
\hline 5. Father - lenient attitude & & & .028 & & & .084 \\
\hline 6. Mother - lenient attitude & & & .059 & & & .012 \\
\hline 7. Father - limiting attitude & & & .107 & & & .071 \\
\hline 8.Mother - limiting attitude & & & .057 & & & .031 \\
\hline
\end{tabular}

${ }^{*} \mathrm{p}<.05,{ }^{* *} \mathrm{p}<.01,{ }^{* * *} \mathrm{p}<.001$.

In the first regression analysis, parenting styles explained $6.5 \%$ of the variance in Peer Relationships. In the model, the greatest unique contribution (and only statistically significant) is given by the cold attitude of the mother $(\beta=-, 180$, $\mathrm{p}<, 05$ ).

In the second regression analysis, parenting styles explained $6.3 \%$ of the variance of Self-Behavior Management. In the model, the greatest unique contribution is given by the cold attitude of the mother $(\beta=-, 164, \mathrm{p}<, 05)$.

In the third regression analysis, parental parenting styles explained $9.1 \%$ of Academic behavior variance. In the model, the greatest unique contribution (and only statistically significant) is given by the cold attitude of the mother ( $\beta=-, 194$, $\mathrm{p}<, 05)$.

In the fourth regression analysis, educational style parents explained $7.7 \%$ of the variance of Social Competences (total score of all social competences). In the model, the greatest unique contribution (and only statistically significant) is given by the cold attitude of the mother $(\beta=-, 188, \mathrm{p}<, 05)$.

The relationship between parenting styles and anti-social behavior of students was investigated using the Pearson linear correlation coefficient. 
Table 4. Correlations between parenting styles and students' anti-social behavior

\begin{tabular}{|c|c|c|c|c|c|}
\hline \multicolumn{2}{|c|}{ Variables } & \multirow{2}{*}{$\begin{array}{c}\begin{array}{c}\text { Hostile / } \\
\text { irritable } \\
\text { behavior }\end{array} \\
-.065\end{array}$} & \multirow{2}{*}{$\begin{array}{c}\begin{array}{c}\text { Anti-social / } \\
\text { aggressive } \\
\text { behavior }\end{array} \\
-.083^{\star}\end{array}$} & \multirow{2}{*}{$\begin{array}{c}\begin{array}{c}\text { Insolent / } \\
\text { disruptive } \\
\text { behavior }\end{array} \\
-.082^{\star}\end{array}$} & \multirow{2}{*}{$\begin{array}{c}\begin{array}{c}\text { Anti-social } \\
\text { behavior - } \\
\text { Scale B }\end{array} \\
-.078^{\star}\end{array}$} \\
\hline Father - warm & Pearson Corr. & & & & \\
\hline attitude & Sig. (2-tailed) & .088 & .030 & .032 & .042 \\
\hline \multirow{2}{*}{$\begin{array}{l}\text { Mother - } \\
\text { warm attitude }\end{array}$} & Pearson Corr. & -.071 & $-.096^{\star}$ & $-.097^{\star}$ & $-.088^{\star}$ \\
\hline & Sig. (2-tailed) & .059 & .011 & .010 & .019 \\
\hline \multirow{2}{*}{$\begin{array}{l}\text { Father - cold } \\
\text { attitude }\end{array}$} & Pearson Corr. & $.085^{\star}$ & $.130^{\star *}$ & $.118^{\star \star}$ & $.111^{\star *}$ \\
\hline & Sig. (2-tailed) & .026 & .001 & .002 & .004 \\
\hline \multirow{2}{*}{$\begin{array}{l}\text { Mother - cold } \\
\text { attitude }\end{array}$} & Pearson Corr. & $.134^{\star \star}$ & $.188^{\star *}$ & $.181^{\star \star}$ & $.168^{\star *}$ \\
\hline & Sig. (2-tailed) & .000 & .000 & .000 & .000 \\
\hline \multirow{2}{*}{$\begin{array}{l}\text { Father - leni- } \\
\text { ent attitude }\end{array}$} & Pearson Corr. & $-.126^{\star *}$ & $-.148^{\star *}$ & $-.158^{\star *}$ & $-.146^{\star *}$ \\
\hline & Sig. (2-tailed) & .001 & .000 & .000 & .000 \\
\hline \multirow{2}{*}{$\begin{array}{l}\text { Mother - leni- } \\
\text { ent attitude }\end{array}$} & Pearson Corr. & $-.103^{\star *}$ & $-.132^{\star \star}$ & $-.125^{\star *}$ & $-.121^{\star *}$ \\
\hline & Sig. (2-tailed) & .006 & .000 & .001 & .001 \\
\hline \multirow{2}{*}{$\begin{array}{l}\text { Father - limit- } \\
\text { ing attitude }\end{array}$} & Pearson Corr. & .047 & $.109^{* *}$ & .065 & .073 \\
\hline & Sig. (2-tailed) & .219 & .004 & .087 & .055 \\
\hline \multirow{2}{*}{$\begin{array}{l}\text { Mother - lim- } \\
\text { iting attitude }\end{array}$} & Pearson Corr. & .070 & $.119^{* *}$ & $.085^{\star}$ & $.092^{\star}$ \\
\hline & Sig. (2-tailed) & .065 & .002 & .025 & .015 \\
\hline
\end{tabular}

Based on the correlation analysis, it is apparent that the parenting styles of the father and mother are notably associated with aggressive behavior in their children (Table 4). The perceived behaviors of fathers and mothers show a similar pattern of association with the measure of children's anti-social behavior: greater maternal and paternal warmth and lenience are associated with lower levels of anti-social behavior, whereas higher levels of cold and limiting maternal and paternal behavior are associated with higher levels of anti-social behavior in children. The cold attitude of the mother is mostly related to the presence of anti-social behavior.

In order to more precisely examine the relationship between predictor and dependent variables, four standard multiple regression analyzes were performed (Tables 5 and 6). 
Table 5. Standard regression analysis for dependent variables Hostile/irritable behavior and Anti-social/aggressive behavior

\begin{tabular}{|c|c|c|c|c|}
\hline \multirow[b]{2}{*}{ Predictors } & \multicolumn{2}{|c|}{ Hostile/irritable behavior } & \multicolumn{2}{|c|}{$\begin{array}{c}\text { Anti-social/aggressive } \\
\text { behavior }\end{array}$} \\
\hline & $\mathrm{R} 2$ & B & $\mathrm{R} 2$ & $\mathrm{~F}$ \\
\hline Parental styles & .030 & $2.587^{\star \star}$ & .051 & $4.524^{\star *}$ \\
\hline 1. Father - warm attitude & & -.039 & & -.035 \\
\hline 2. Mother - warm attitude & & -.017 & & -.019 \\
\hline 3. Father - cold attitude & & .106 & & .169 \\
\hline 4. Mother - cold attitude & & $.203^{*}$ & & $.293^{\star *}$ \\
\hline 5. Father - lenient attitude & & -.128 & & -.126 \\
\hline 6. Mother - lenient attitude & & -.005 & & -.022 \\
\hline 7. Father - limiting attitude & & .069 & & .036 \\
\hline 8.Mother - limiting attitude & & .072 & & .010 \\
\hline
\end{tabular}

Table 6. Standard regression analysis for dependent variables insolent/disruptive behavior and anti-social behavior - Scale B

\begin{tabular}{|c|c|c|c|c|c|}
\hline & Hosti & irritable behavior & & Scale B & \\
\hline Predictors & $R^{2}$ & $\begin{array}{ll}F & \text { B } \\
\end{array}$ & $R^{2}$ & $F$ & $\beta$ \\
\hline Parental styles & .052 & $4.601^{\star * *}$ & .043 & $3.794^{\star *}$ & \\
\hline $\begin{array}{l}\text { 1. Father - warm } \\
\text { attitude }\end{array}$ & & -.075 & & & -.049 \\
\hline $\begin{array}{l}\text { 2. Mother - warm } \\
\text { attitude }\end{array}$ & & -.003 & & & -.012 \\
\hline $\begin{array}{l}\text { 3. Father - cold } \\
\text { attitude }\end{array}$ & & .172 & & & .145 \\
\hline $\begin{array}{l}\text { 4. Mother - cold } \\
\text { attitude }\end{array}$ & & $.312^{* *}$ & & & $.266^{\star *}$ \\
\hline $\begin{array}{l}\text { 5. Father - lenient } \\
\text { attitude }\end{array}$ & & -.195 & & & -.151 \\
\hline $\begin{array}{l}\text { 6. Mother - lenient } \\
\text { attitude }\end{array}$ & & -.034 & & & -.001 \\
\hline $\begin{array}{l}\text { 7. Father - limiting } \\
\text { attitude }\end{array}$ & & .023 & & & .027 \\
\hline $\begin{array}{l}\text { 8.Mother - limit- } \\
\text { ing attitude }\end{array}$ & & .019 & & & .042 \\
\hline
\end{tabular}


In the first regression analysis, parenting styles explained $3 \%$ of the variance in the hostile/irritable behavior. In the model, the greatest unique contribution (and only statistically significant one) is given by the mother's cold attitude $(\beta=, 203$, $\mathrm{p}<, 05)$.

In the second regression analysis, parenting educators explained $6.1 \%$ of the anti-social/aggressive behavior variance. In the model, the greatest unique contribution (and only statistically significant one is given by mother's cold attitude $(\beta=, 293, \mathrm{p}<, 01)$.

In the third regression analysis, parenting styles explained $5.2 \%$ of the variance of Insolent/ disruptive behavior. In the model, the greatest unique contribution (and only statistically significant) is given by the cold attitude of the mother ( $\beta=$ $, 312, \mathrm{p}<, 01)$.

In the fourth regression analysis, parenting styles explained $4.3 \%$ of the variance of Anti-social behavior (total score of all forms of anti-social behavior). In the model, the greatest unique contribution (and only statistically significant) is given by the cold attitude of the mother $(\beta=, 266, \mathrm{p}<, 01)$.

\section{Discussion and Conclusions}

Summarizing the results of the research, it was shown that the warm-lenient parenting style can be associated with the most desirable developmental outcomes in children: a high level of competence, self-confidence, independence, higher academic achievement, adequate self-control and responsible behavior. The established relations are expected, because various research continuously explain the importance of parental warmth as a predictor of children's social behavior. Previous research have confirmed that parental lenience and warmth are positively correlated with social competences in children, while a cold and limiting attitude lead to the development of inadequate social competences (Maccoby \& Martin, 1983, according to Darling \& Steinberg, 1993; Grolnick \& Ryan, 1989; Hart et al., 2003). In addition, the regression analysis conducted in this study clearly indicates a very pronounced negative predictability of a mother's cold attitude towards lower levels of social competence of the students in all examined factors. The results show that the mother is a central figure to children, implying that love, warmth, understanding and support are expected in the relationship with the mother. In families where there are no such parent-child relationships, there is a high probability for children not to develop desirable social skills and com- 
petences, potentially conditioning the development of unwanted behaviors, both manifest and experiential.

In terms of correlation between parenting styles and anti-social behavior of the students, the negative prediction of cold and limiting behavior of mothers and fathers in relation to anti-social behavior of students is consistent with some previous research (Deković\& Janssens, 1992; Chao, 2001; Rigby, 2013). Patterson et al. (1989) state that parental behavior and family processes explain $30-40 \%$ of the variance in aggressive and anti-social behavior. In our research that percentage is smaller, but it is very important to point out that in all four regression analyses, the cold attitude of the mother stands out as a pronounced predictor of anti-social behavior of students in all observed factors. Thus, the negative pole of the affective dimension of the mother, that is, the cold and distant behavior of the mother, results in anti-social behavior in children.

Cross-cultural research provide a solid basis for concluding that children and young people who have experienced a rejecting (cold) relationship with their parents - regardless of differences in culture, ethnicity, language, gender or race - exhibit specific forms of poor psychological adaptation that include problems with control of hostility, aggression and passive-aggression, an impaired sense of competence, emotional instability and a negative worldview (Rohner, 2004). Also, it is significant to mention that the role of the mother in Serbian patriarchal culture is usually associated with warmth, gentleness and love shown towards children. A disruption in this relationship leads to distance and division between mother and child and causes emotional coldness in the mother's actions. This can be frustrating and discouraging for children, something which in turn encourages the manifestation of anti-social tendencies in their children's behavior.The results obtained in the research also support the view that, in general, those children who do not have an adequate emotional connection with their mother, whose mothers are emotionally cold and rejecting, have a higher risk of becoming violent.

Summarizing research results, it could be concluded that parental upbringingin measures in the forms of punishment, coercion, and emotional rejection and cold, indifferent behavior, particularly mothers, can serve children as an inadequate model that they might imitate and implement in their behavior. Therefore, as long as parents use "reasonable authority" or "authoritative control", showing love and interest, warmth and understanding, children will have more pronounced social competence and fewer problems in behavior and communication in all living environments. 


\section{References}

Baumrind, D. (1966). Effects of authoritative parental control on child behavior. Child Development, 37 (4), 887-907.

Darling, N., \& Steinberg, L. (1993). Parenting style as context: An integrative model. Psychological Bulletin, 113 (3), 487-496.

Deković, M., \& Janssens, J.M. (1992). Parents' child-rearing style and child's sociometric status. Developmental Psychology, 28 (5), 925-932.

Genc, L., \& Kodžopeljić, J. (1995). Porodično vaspitanje i dimenzije ličnosti [Family upbringing and personality dimensions]. $\mathrm{U}$ Đ. Đurić (ur.): Ličnost u višekulturnom društvu [Personality in Multicultural Society], 2 (pp. 70-81). Novi Sad: Filozofski fakultet.

Grolnick, W.S., \& Ryan, R.M. (1989.). Parent styles associated with children's self-regulation and competence in school. Journal of Educational Psychology, 81 (2), 143-154.

Hart, C.H., Newell, L.D., \& Olsen, S.F. (2003). Parenting skills and social communicative competence in childhood. In J.O. Greene \& B.R. Burleson (Eds.), Handbook of communication and social interaction skills (pp. 753-797). Mahwah, NJ: Lawrence Erlbaum Associates.

Kopko, K. (2007). Parenting styles and adolescents. Informally published manuscript, Cooperative Extension. Ithaca, New York: Cornell University.

Merrell, K.W. (2002). School Social Behavior Scales. (2end ed.) Eugene OR: Assessment Intervention Resources.

Patterson, G., DeBaryshe, B., \& Ramsey, E. (1989). A Developmental Perspectives on Antisocial Behavior. American Psychologist, 44 (2), 329-335.

Petrović, J. (2008). Socijalna kompetencija - konceptualna i teorijska pitanja [Social competence - Conceptual and theoretical Issues]. Teme, 32 (3), 611-623.

Rigby, K. (2013). Bullying in schools and its relation to parenting and family life. Family matters, 92, 61-67.

Rohner, R.P. (2004). The Parental "Acceptance-Rejection Syndrome": Universal Correlates of Perceived Rejection. American Psychologist, 59 (8), 830-840.

Schaefer, E.S. (1959). A circumplex model for maternal behavior. The Journal of Abnormal and Social Psychology, 59 (2), 226-235.

Steinberg L. (2001). We know some things: Parent-adolescent relationships in retrospect and prospect. Journal of research on adolescence, 11 (1), 1-19.

Walker, H.M., Colvin, G.,\&Ramsey, E. (1995). Antisocial behavior in school: Strategies and best practices. Pacific Grove, CA: Brooks/Cole Publishing Company. 